\title{
EVALUASI KESESUAIAN LAHAN PERTANAMAN PADI PADA LAHAN PERTANAMAN PADI SAWAH IRIGASI
}

\author{
Yulis Tiana Wati, Fahri, Niar Nurmauli \& Tamaluddin Syam \\ Jurusan Agroteknologi, Fakultas Pertanian Universitas Lampung \\ J1. Prof. Soemantri Brodjonegoro, No.1, Bandar Lampung 35145 \\ Email : nda_yulis@yahoo.com
}

\begin{abstract}
ABSTRAK
Padi merupakan tanaman penghasil beras yang menjadi tanaman pangan utama di Indonesia.produksi beras yang sedikit mengharuskan indonesia menginport beras dalam upaya mencukupi kebutuhan pangannya. Evaluasi kesesuaian lahan merupakan penilaian dan pendugaan potensi lahan untuk penggunaan tertentu. Dengan evaluasi lahan tersebut, potensi lahan dapat dinilai dengan tingkat pengelolaan yang dilakukan. Penelitian ini dilakukan pada Kelompok Tani Sri Mulya Desa Pringgondani Kecamatan Sukadana Lampung Timur. Evaluasi kesesuaian lahan yang dilakukan menggunakan kriteria biofisik menurut Djaenuddin dkk. (2000), dan penilaian secara ekonomi dengan menganalisa kelayakan finansial dengan menghitung nilai NPV, Net B/C Ratio, dan IRR. Hasil penelitian ini menunjukkan, bahwa lahan pertanaman padi pada Kelompok Tani Sri Mulya Desa Pringgondani Kecamatan Sukadana Lampung Timur menurut kriteria Djaenuddin dkk. (2000) adalah cukup sesuai (S2) dengan faktor pembatas KTK, pH, dan C-organik (nr) (S2nr) dan usaha tani pada lokasi penelitian secara finansial layak untuk dilanjutkan dengan nilai rata-rata NPV sebesar Rp 32.315059,-, Net B/C 2,66 bulan'- dan IRR 44,88\%.
\end{abstract}

Kata kunci : Evaluasi lahan, usaha tani padi

\section{PENDAHULUAN}

Indonesia merupakan negara agraris yang menjadikan sektor pertanian sebagai sektor utama dalam pembangunan perekonomian di Indonesia, karena sekitar $70 \%$ penduduk di Indonesia bergantung pada sektor pertanian sebagai sumber kehidupan utama (Tjahjadi, 1995).

Kesesuaian lahan (land suitability) merupakan potensi lahan yang didasarkan atas kesesuaian lahan untuk penggunaan pertanian secara lebih khusus, seperti padi. Penentuan kesesuaian lahan dilakukan dengan cara membandingkan karakteristik dan kualitas lahan dengan persyaratan pengunaan lahan untuk suatu tanaman tertentu. Nilai kesesuaian lahan ditentukan oleh adanya faktor penghambat dan tingkat dari faktor penghambat tersebut. Semakin besar tingkatan faktor penghambat yang ada, membuat kesesuaian lahan semakin berkurang. Selain ditinjau dari kesesuaian lahannya maka diperlukan juga suatu informasi mengenai kelayakan baik itu kelayakan ekonomi, kelayakan sosial maupun kelayakan finansial suatu penggunaan lahan.

Produksi padi pada lahan pertanaman padi sawah irigasi di Desa Pringgondani Kecamatan Sukadana Kabupaten Lampung Timur khususnya pada Kelompok Tani Sri Mulya sering mengalami penurunan pada musim tertentu, sehingga dibutuhkan penelitian ini untuk membantu petani di Desa Pringgondani Kecamatan
Sukadana Kabupaten Lampung Timur agar petani mengetahui keadaan lahan pertanaman padi sawah irigasi yang digunakan selama ini sudah cukup sesuai atau belum untuk pertanaman padi sawah irigasi. Penelitian ini juga diharapkan dapat memberikan masukan pada petani tentang upaya pengelolaan lahan yang dapat dilakukan, apabila hasil penelitian menunjukkan adanya ketidak kesesuaian lahan pada pertanaman padi sawah irigasi di Desa Pringgondani Kecamatan Sukadana Kabupaten Lampung Timur yang dinilai memiliki potensi untuk dikembangkan dan secara kuantitatif (ekonomi) hasilnya sangat menguntungkan.

Pada penelitian ini dilakukan cara penilaian kesesuaian lahan secara fisik berdasarkan kriteria Djaenuddin dkk.(2000), sedangkan evaluasi kesesuaian lahan kuantitatif dilakukan dengan menilai kelayakan finansial usaha tani tanaman padi dengan cara menghitung $N P V$, Net $B / C$, dan IRR.

Penelitian ini bertujuan untuk mengevaluasi kesesuaian lahan kualitatif pertanaman padi sawah irigasi Pada Lahan Kelompok Tani Sri Mulya Desa Pringgondani Kecamatan Sukadana Kabupaten Lampung Timur, berdasarkam kriteria Djaenuddin dkk. (2000) dan mengevaluasi kesesuaian lahan kuantitatif dengan menganalisis nilai kelayakan finansial budidaya tanaman Padi sawah irigasi Pada Lahan Kelompok Tani Sri Mulya Desa Pringgondani Kecamatan Sukadana Kabupaten Lampung Timur . 


\section{BAHAN DAN METODE}

Penelitian dilaksanakan pada lahan pertanaman padi Kelompok Tani Sri Mulya Desa Pringgondani Kecamatan Sukadana Kabupaten Lampung Timur, dengan areal pertanaman padi yang diteliti seluas 10 ha dari total luas seluruh areal pertanaman padi di Pringgondani seluas 15 ha. Penelitian ini dilakukan pada bulan Mei 2012 sampai Juli 2012.

Alat-alat yang digunakan adalah bor tanah, meterean, kantong plastik, kamera digital, buku munsell colour soil chart, global positioning system (GPS), alatalat tulis, alat-alat laboratorium. Bahan-bahan yang digunakan dalam penelitian adalah contoh tanah yang diambil secara komposit dari 5 titik dengan kedalaman 0-20 cm dan profil boring sampai kedalaman $120 \mathrm{~cm}$, serta bahan-bahan kimia yang digunakan untuk analisis tanah.

Evaluasi lahan dilakukan dengan cara mengevaluasi kesesuaian lahan kualitatif dengan membandingkan kualitas lahan terhadap kriteria kesesuaian lahan menurut kriteria Djaenudin, dkk. (2000) serta mengevaluasi kelayakan finansial dilakukan dengan menghitung nilai Net Present Value (NPV), Net Benefit Cost Ratio (Net B/C) dan Internal Rate of Return (IRR).

Pelaksanaan penelitian ini dilakukan dengan menggunakan beberapa tahap, yaitu persiapan penelitian, prasurvei, pengumpulan data, pengamatan lapang, pengambilan contoh tanah, analisis tanah di laboratorium, analisis data.

\section{HASIL DAN PEMBAHASAN}

Penilaian kesesuaian lahan kualitatif berdasarkan kriteria biofisik untuk tanaman padi sawah irigasi berdasarkan pada kualitas dan karakteristik.

Berdasarkan data temperatur rata-rata tahunan yang didapatkan dari Badan Meteorologi Klimatologi dan Geofisika (BMKG) Stasiun Klimatologi Masgar Lampung, daerah lokasi penelitian memiliki temperatur rata-rata tahunan sebesar $26,7^{\circ} \mathrm{C}$. Temperatur rata-rata tahunan daerah lokasi penelitian dapat digolongkan ke dalam kelas kesesuaian lahan sangat sesuai (S1).

Penilaian ketersediaan dilakukan dengan mengamati data kelembaban udara. Berdasarkan data BMKG Stasiun Klimatologi Masgar Lampung kelembaban udara rata-rata di daerah penelitian $83 \%$, sehingga menurut kriteria Djaenudin dkk. (2000) tergolong ke dalam kelas kesesuaian lahan sangat sesuai (S1).
Penentukan penilaian media perakaran pada lahan penelitian, karakteristik lahan yang diamati adalah drainase, tekstur tanah, bahan kasar, dan kedalaman tanah.Daerah penelitian mempunyai drainase yang baik, hal ini ditunjukkan oleh hasil pengamatan tiap lapisan pada irisan profil tanah tidak ditemukan adanya karatan, dan tidak ditemukan lapisan padas. Keadaan ini termasuk dalam kelas kesesuaian lahan sangat sesuai (S1).

Berdasarkan hasil analisis laboratorium, tekstur tanah daerah penelitian termasuk dalam kelas lempung liat berpasir dengan persentase kandungan pasir 35,43 $\%$, debu $15,81 \%$, liat 34,67 \% untuk komposit tanah pada kedalaman $(0-20 \mathrm{~cm})$ (Tabel 9, Lampiran), sedangkan untuk komposit tanah pada kedalaman (20$40 \mathrm{~cm}$ ) persentase kandungan pasir 33,76\%, debu 14,43 $\%$, liat $40,45 \%$, keadaan ini termasuk kedalam kelas kesesuaian lahan sangat sesuai (S1). Bahan kasar di daerah penelitian tidak ditemukan $(0 \%)$, sehingga termasuk ke dalam kelas kesesuaian lahan sangat sesuai (S1).

Kedalaman efektif lahan penelitian adalah $>100$ $\mathrm{cm}$, hal ini ditunjukkan pada saat analisis profil pada irisan tanah pada kedalaman tanah $100 \mathrm{~cm}$ tidak ditemukan faktor pembatas bagi perkembangan akar seperti batuan cadas. Dengan demikian menurut kriteria Djaenudin dkk. (2000) tergolong dalam kelas kesesuaian lahan sangat sesuai (S1).

Penilaian retensi hara dilakukan dengan mengamati KTK liat, kejenuhan basa (KB), $\mathrm{pH} \mathrm{H}_{2} \mathrm{O}$ dan kandungan C-organik. Nilai KTK tanah tertimbang berdasarkan hasil analisis laboratorium sebesar 5,125 Cmolc kg-1 sehingga KTK liatnya sebesar 13,64 Cmolc $\mathrm{kg}^{-1}$. Dengan demikian KTK liat di lokasi penelitian tergolong ke dalam kelas kesesuaian lahan cukup sesuai (S2).

Kejenuhan basa tanah tertimbang adalah 50,33 $\%$. Dengan demikian menurut kriteria Djaenudin dkk. (2000) keadaan ini termasuk ke dalam kelas kesesuaian lahan sangat sesuai (S1). pH tanah tertimbang adalah 5,15. Dengan demikian menurun Djaenudin dkk. (2000) keadaan termasuk ke dalam kelas kesesuaian lahan cukup sesuai (S2). C-organik tertimbang adalah $0,83 \%$. Dengan demikian menurut kriteria Djaenudin dkk. (2000) tergolong ke dalam kelas kesesuaian lahan cukup sesuai (S2).

Letak daerah penelitian jauh dari pantai maka salinitas tanah diasumsikan $<2 \mathrm{dsm}^{-1}$, dimana menurut kriteria Djaenudin dkk. (2000) termasuk ke dalam kelas kesesuaian lahan sangat sesuai (S1). 
Penilaian sodisitas dilakukan terhadap alkalinitas. Alkalinitas diukur dengan menggunakan perhitungan berikut :

$$
\begin{aligned}
& E S P=\frac{N a \text { dapat ditukar } \mathrm{cmolc} \mathrm{kg}_{-1} \times 100 \%}{K T K \mathrm{cmolc} \mathrm{kg}_{-1}} \\
& =\frac{0,015 \mathrm{cmolc} \mathrm{kg}-1_{1} \times 100 \%}{5,125 \mathrm{cmolc} \mathrm{kg}-1^{-1}} \\
& =0,29 \%
\end{aligned}
$$

Dengan demikian daerah penelitian menurut kriteria Djaenuddin dkk. (2000) termasuk kedalam kelas kesesuaian lahan sangat sesuai (S1).

Lahan pada lokasi penelitian adalah lahan yang letaknya jauh dari pantai yang tidak dipengaruhi oleh pasang surut air laut. Selain itu, pada daerah penelitian juga tidak terdapat lahan gambut serta tidak ditemukan bahaya sulfidik yang mengandung senyawa pirit $\left(\mathrm{Fe}_{2} \mathrm{~S}\right)$. Dengan demikian dapat diperkirakan daerah tersebut tidak dipengaruhi oleh sulfidik sehingga dapat diasumsikan kedalaman sulfidik lokasi penelitian $>120$ $\mathrm{cm}$, sehingga masuk ke dalam kelas kesesuaian lahan sangat sesuai (S1).

Berdasarkan hasil pengamatan pada daerah penelitian diketahui bahwa lokasi penelitian mempunyai topografi datar dengan kemiringan lereng $2 \%$, sehingga memiliki tingkat bahaya erosi tergolong sangat ringan, maka termasuk kedalam kelas kesesuaian lahan sangat sesuai (S1).

Penilaian bahaya banjir dilakukan terhadap genangan. Berdasarkan hasil peng-amatan di lapangan dan wawancara dengan petani setempat, pada lahan penelitian tidak pernah terdapat genangan banjir yang terjadi lebih dari 24 jam, sehingga termasuk ke dalam kelas kesesuaian lahan sangat sesuai (S1).

Penilaian penyiapan lahan dilakukan terhadap jumlah batuan dipermukaan dan singkapan batuan. Dari hasil pengamatan di lapangan tidak ditemukan batuan dipermukaan dan singkapan batuan, sehingga termasuk ke dalam kelas kesesuaian lahan sangat sesuai (S1).

Biaya usahatani tanaman padi terdiri dari biaya tetap dan biaya variabel. Biaya tetap terdiri dari biaya sewa tanah, sewa alat, biaya irigasi dan pembelian peralatan pertanian. Biaya untuk menyewa sebidang tanah seluas 1 Ha adalah sebesar Rp. 1.600.000,- untuk 1 musim tanam. Peralatan pertanian yang disewa adalah hand traktor. Biaya menyewa hand traktor untuk pengolahan tanah seluas 1 Ha adalah Rp. 500.000,- untuk 1 musim tanam. Peralatan pertanian yang dibeli adalah cangkul, koret, sprayer, sabit bergerigi, dan karung. Sedangkan biaya irigasi adalah sebesar Rp. 300.000,- untuk 1 musim tanam. Biaya variabel terdiri atas biaya sewa mesin penggiling padi, sewa transportasi, pembelian benih, pembelian pupuk kimia, pembelian pestisida, dan upah tenaga kerja.

Penerimaan pada analisis finansial usaha tani tanaman padi sawah irigasi pada kelompok tani sri mulya ini bersumber dari hasil penjualan padi yang harganya Rp 3.200,- $\mathrm{kg}^{-1}$ sampai dengan Rp 3.500,- $\mathrm{kg}^{-1}$. Sedangkan untuk produksi padi dari tahun 2010-2011 selalu berfluktuasi antara 3,200 sampai 5,200. Penerimaan dari penjualan padi pada tiap musim tanam berkisar antara Rp. 11.520.000,- ha-1 hingga Rp. 17.850.000,- ha $^{-1}$ sehingga total penerimaan rata-rata usaha budidaya padi selama empat musim berkisar antara Rp. 14.153.750,- ha ${ }^{-1}$ sampai Rp. 15.705.000,$\mathrm{ha}^{-1}$.

Analisis finansial dilakukan dengan menghitung nilai penerimaan bersih sekarang, nilai perbandingan antara penerimaan bersih dan biaya serta nilai tingkat pengembalian internal dengan menggunakan tingkat suku bunga yang berlaku di masyarakat saat ini. Tingkat suku bunga yang berlaku diasumsikan sebesar $15 \%$. Penerimaan bersih sekarang (NPV) selama 12 bulan (1 tahun) dilakukannya usaha tani tanaman padi per hektar sebesar Rp 33.804.927,- perbandingan antara penerimaan bersih dan biaya sebesar (Net B/C) sebesar 2,74 , tingkat pengembalian internal (IRR) sebesar $43,55 \%$.

Kesesuaian Lahan didasarkan pada Kriteria Biofosik Menurut Djaenuddin dkk (2000). Berdasarkan hasil analisis didapat faktor pembatas terberat adalah retensi hara yaitu $\mathrm{KTK}$, $\mathrm{pH}$ dan $\mathrm{C}$-organik sehingga sub kelas kesesuaian lahannya adalah cukup sesuai (S2nr). Nilai KTK pada lahan penelitian sebesar 13,64 $\mathrm{cmol}_{\mathrm{c}} / \mathrm{kg}$, menurut kriteria Djaenuddin dkk. (2000) termasuk kedalam kelas kesesuaian lahan cukup sesuai (S2). Hal ini dapat ditanggulangi dengan pemberian bahan organik yang bertujuan untuk meningkatkan daya jerap tanah terhadap ion-ion yang bermuatan positif seperti unsur $\mathrm{K}, \mathrm{Ca}, \mathrm{Mg}$ dan $\mathrm{Na}$.

Nilai pH pada lahan penelitian sebesar 5,15, menurut kriteria Djaenuddin dkk.(2000) termasuk kedalam kelas kesesuaian lahan cukup sesuai (S2). Hal ini dapat ditanggulangi dengan cara pemberian kapur dan pemberian bahan organik yang bertujuan untuk meningkatkan $\mathrm{pH}$ tanah yang cocok untuk pertumbuhan padi sawah irigasi.

Nilai C-organik pada lahan penelitian sebesar 0,83 $\%$, menurut kriteria Djaenuddin dkk. (2000) termasuk kedalam kelas kesesuian lahan cukup sesuai (S2), ketiga karakteristik lahan ini merupakan faktor pembatas bagi penilaian kelas kesesuaian lahan tanaman padi. 
Tanaman padi di lokasi penelitian dipupuk dengan pupuk kandang (kotoran sapi dan unggas) sebesar $10 \mathrm{t}$ ha $^{-1}$ musim $^{-1}$, pemberian pupuk kimia Urea dan SP-36 / Ponska dengan dosis pupuk masing-masing sebanyak $50 \mathrm{~kg}$. Menurut Souri (2001), kebutuhan pupuk kandang (organik) untuk lahan seluas 1 ha adalah antara 10 - 20 ton, tergantung dari tingkat kesuburan tanah.

Pemberian pupuk kandang di lokasi penelitian belum dapat mencukupi kebutuhan tanaman padi, dengan kata lain dosis pupuk kandang yang diberikan tiap musimnya belum cukup untuk mengatasi kekurangan kandungan bahan organik di dalam tanah. Oleh sebab itu, salah satu penyebab yang membuat kandungan Corganik tanah pada lahan tersebut rendah selain terbawa oleh panen juga disebabkan oleh kurangnya pemberian pupuk kandang. Untuk meningkatan kandungan Corganik dapat dilakukan dengan pemberian pupuk organik, baik berasal dari pupuk kandang maupun sisa tanaman yang dikembalikan ke lahan pada saat panen (Souri, 2001).

Selain pupuk organik, jerami padi juga dapat digunakan sebagai penyedia unsur hara dan bahan organik. Menurut Munif (2009), potensi jerami kurang lebih 1,4 kali dari hasil panen. Rata-rata produktivitas padi nasional adalah $48,95 \mathrm{ku} / \mathrm{ha}$, sehingga jumlah jerami yang dihasilkan kurang lebih $68,53 \mathrm{ku} \mathrm{ha}^{-1}$. Produksi padi nasional tahun 2008 sebesar 57,157 juta ton, dengan demikian produksi jerami nasional diperkirakan mencapai 80,02 juta ton.

Evaluasi kesesuaian lahan tanaman padi pada penelitian ini dilakukan tidak terpisah karena biaya yang dikeluarkan saling berhubungan. Biaya produksi pada awal dimulainya musim tanam lebih besar karena besarnya biaya pengeluaran sewa tanah, pembelian alat pertanian sebagai biaya tetap dan pengolahan tanah sebagai biaya variabel.

Penerimaan pada analisis finansial usahatani padi pada kelompok tani Sri Mulya ini bersumber dari hasil penjualan gabah kering giling yang harganya berubah dari harga Rp 3.200,- sampai dengan Rp 3.500,-Sedangkan untuk produksi gabah kering giling relatif berbeda-beda, hal ini dapat dilihat dari jumlah produksi gabah kering giling berubah-ubah di setiap musim tanam.

Penerimaan setiap musim tanam kedua dan keempat selalu mengalami penurunan dibandingkan pada musim tanam pertama dan ketiga. Pada musim tanam pertama dan kedua diperoleh penerimaan sebesar Rp 16.480.000,- dan Rp13.440.000,- serta pada musim tanam ketiga dan keempat sebesar Rp17.675.000,- dan Rp 15.225.000,-. Total penerimaan rata-rata usahatani padi selama empat musim tanam adalah sebesar Rp59.286.000,-
Untuk mengetahui tingkat kelayakan usahatani padi digunakan analisis $N P V$, Net $B / C$, dan IRR. NPV (nilai sekarang pendapatan bersih) merupakan selisih nilai sekarang pendapatan dengan nilai sekarang investasi selama umur ekonomis tanaman padi. Tingkat suku bunga yang digunakan adalah $15 \%$ yang merupakan suku bunga yang berlaku di masyarakat saat ini. Dari hasil pengolahan data, diperoleh nilai NPV petani Nyoman sebesar Rp 33.804.927,- yang berarti bahwa selama 4 musim tanam usahatani padi petani Nyoman akan memberikan nilai pendapatan bersih sebesar Rp 33.804.927,-. Sedangkan nilai NPV petani responden sebesar Rp 32.149.518,- yang berarti bahwa selama 4 musim tanam usahatani padi petani responden akan memberikan nilai pendapatan bersih sebesar $\mathrm{Rp}$ 32.149.518,-. Berdasarkan besarnya nilai NPV, maka usahatani padi petani Nyoman lebih menguntungkan dibandingkan usahatani petani responden, hal ini ditunjukkan oleh nilai NPV petani Nyoman lebih besar dibandingkan nilai NPV petani responden, akan tetapi karena nilai NPV petani Nyoman dan petani responden lebih dari 0 dengan demikian dapat dikatakan bahwa usahatani padi tersebut layak untuk diusahakan.

Net B/C ratio (rasio biaya manfaat bersih) adalah perbandingan antara nilai manfaat bersih dengan biaya bersih yang diperhitungkan nilainya saat ini. Discount dan compound rate yang digunakan adalah $15 \%$. Net $\mathrm{B} / \mathrm{C}$ petani Nyoman yang diperoleh dari hasil pengolahan data selama 4 musim tanam adalah 2,74. Berarti setiap Rp 1,00 yang diinvestasikan selama 4 musim tanam akan memberikan pengembalian sebesar 2,74. Sedangkan Net $\mathrm{B} / \mathrm{C}$ petani responden yang diperoleh dari hasil pengolahan data selama 4 musim tanam adalah 2,64. Berarti setiap Rp 1,00 yang diinvestasikan selama 4 musim tanam akan memberikan pengembalian sebesar 2,64, dan usaha tani padi ini layak atau menguntungkan. Berdasarkan besarnya nilai Net B/C, maka usahatani padi petani Nyoman lebih menguntungkan dibandingkan usahatani petani responden, hal ini ditunjukkan oleh nilai Net B/C petani Nyoman lebih besar dibandingkan nilai $\mathrm{Net} B / \mathrm{C}$ petani responden, akan tetapi karena nilai Net $\mathrm{B} / \mathrm{C}$ petani Nyoman dan petani responden lebih dari 1 dengan demikian dapat dikatakan bahwa usahatani padi tersebut layak untuk diusahakan.

IRR atau tingkat investasi adalah suatu tingkat bunga dimana nilai sekarang pendapatan sama dengan nilai sekarang investasi. Tingkat suku bunga yang berlaku diasumsikan sebesar $15 \%$ setahun dan suku bunga perbulannya sebesar $1.25 \%$. Nilai suku bunga ini digunakan sebagai compounding factor (CF), hal ini disebabkan karena perhitungan finansial dilakukan pada data yang lalu (2010-2011). 
Dari hasil pengolahan data diperoleh nilai IRR petani Nyoman selama 4 musim tanam sebesar 43,55 $\%$ per bulan. Hal ini menyatakan bahwa pada tingkat suku bunga di bawah 43,55\% usahatani padi masih layak untuk dikembangkan, apabila tingkat suku bunga melebihi $43,55 \%$ usahatani padi sudah tidak layak lagi untuk dikembangkan karena secara finansial sudah tidak menguntungkan. Sedangkan nilai IRR petani responden selama 4 musim tanam sebesar $45,03 \%$ per bulan. Hal ini menyatakan bahwa pada tingkat suku bunga di bawah 45,03\% usahatani padi masih layak untuk dikembangkan, apabila tingkat suku bunga melebihi 45,03\% usaha tani padi sudah tidak layak lagi untuk dikembangkan karena secara finansial sudah tidak menguntungkan.

Nilai IRR pada petani Nyoman dan petani responden nilainya jauh lebih tinggi dibandingkan dengan nilai interval rate perbulan yaitu $1,25 \%$, maka usahatani layak untuk dikembangkan atau menguntungkan.

Dari hasil perhitungan IRR yang di dapat, menunjukkan bahwa nilai IRR rata-rata dari usahatani padi di Desa Pringgondani Kecamatan Sukadana Lampung Timur nilainya sebesar 44,29\% per bulan lebih tinggi dari tingkat suku bunga awal yang telah ditentukan yaitu $1,25 \%$ per bulan, meskipun kesesuaian lahan kualitatifnya termasuk ke dalam kelas kesesuaian lahan S2nr, akan tetapi di segi kelayakan finansialnya usahatani padi sawah irigasi di lokasi penelitian menguntungkan dan layak untuk diteruskan.

\section{KESIMPULAN}

Lahan Penelitian milik Kelompok Tani Sri Mulya Desa Pringgondani Kecamatan Sukadana Lampung Timur menurut criteria Djaenudin dkk. (2000) memiliki kelas kesesuaian lahan cukup sesuai dengan faktor pembatas KTK, pH dan C-organik (S2nr) untuk tanaman padi sawah irigasi. Secara finansial, usaha budidaya tanaman padi sawah irigasi Kelompok Tani Sri Mulya Desa Pringgondani Kecamatan Sukadana Lampung Timur menguntungkan dan layak untuk dikembangkan. Hal ini dibuktikan dari hasil perhitungan rata-rata yang menunjukkan bahwa nilai NPV rata-rata sebesar Rp32.977.222,-. Net B/C rata-rata sebesar 2,69 yang nilainya lebih dari 1 (Net $\mathrm{B} / \mathrm{C}>1)$ usaha tani menguntungkan dan IRR rata-rata sebesar 44,29 per bulan yang nilainya lebih besar dari tingkat suku bunga yang berlaku saat ini yang diasumsikan sebesar 1,25\% per bulan atau $15 \%$ per tahun.

\section{DAFTAR PUSTAKA}

Djaenuddin, D., H. Marwan, H. Subagyo, A. Mulyani dan N. Suharta. 2000. Kriteria Kesesuaian Lahan untuk Komoditas Pertanian. Departemen Pertanian. 264 hlm.

Djaenudin, D., H. Marwan, H. Subagyo, dan A. Hidayat. 2003. Petunjuk Teknis untuk Komoditas Pertanian. Edisi Pertama tahun 2003, ISBN 9799474-25-6. Balai Penelitian Tanah, Pusat Penelitian dan Pengembangan Tanah dan Agroklimat. Bogor.

Tjahjadi. 1995. Kesesuaian Lahan untuk Pengembangan Pertanian, Daerah Rekreasi dan Bangunan. Jurusan Tanah Fakultas Pertanian Institut Pertanian Bogor. Bogor. 381 hlm.

Munif, A. 2009. Pemanfaatan Jerami Padi sebagai Pupuk Organik In-Situ untuk Mengurangi Penggunaan Pupuk Kimia dan Subsidi Pupuk. Universitas Gadjah Mada Press. Yogyakarta. Diakses tanggal 30 Juli 2012 dari http:// isroi.wordpress.com/2009/05/14/pemanfaatanjerami-padi-sebagai-pupuk-organik-in-situ-untukmengurangi-penggunaan-pupuk-kimia-dansubsidi-pupuk/.

Souri, S. 2001. Penggunaan Pupuk Kandang Meningkatkan Produksi Petani. Instalasi Penelitian dan Pengkajian Teknologi Pertanian Mataram. Diakses tanggal 1 Agustus 2012 dari litram@mataram.wasantara.net.id. 